\title{
Attainment of higher level of blooms taxonomy through open ended activity in metrology \& quality engineering lab
}

\author{
N.Vijayakumar', \\ Madhusudhana $\mathbf{H} \mathbf{K}^{3}$, V.N.Gaitonde', \\ ,Praveen kumar, \\ Department of Industrial\& Production Engineering \\ B.V.B. College of engineering \& Technology, \\ Hubli-580 031, Karnataka, India \\ 1vijaykumar@bvb.edu, _vngaitonde@bvb.edu, \\ 3madhusudhana@bvb.edu,_4anandl@bvb.edu, \\ spraveenkumar@bvb.edu
}

\begin{abstract}
Blooms Taxonomy is a framework for classifying statements of what faculty expect or intend students to learn as a result of instruction. Bloom's Taxonomy provides an important framework for faculty to focus on higher order thinking, by providing a hierarchy of levels, this taxonomy can assist faculty in designing performance tasks, crafting questions for conferring with students, and providing feedback on student work. Achieving higher order of learning in some courses is challenging task for a faculty so an effort is made in this course to how a remembering level concept can be taken to analyzing level through an open ended activity.

In a process manufacturing the variation occurs because of part to part variation and measurement variation in turn the measurement variation is due to operator involving in measurement (Reproducibility) or the variation due to the gage(Repeatability) and it is popularly known as Gage R\&R so this concept, students study in the metrology and quality engineering subject which will be addressing only remembering level of blooms taxonomy so in order to give an experiential learning and in order to achieve higher level of blooms level an open ended activity is designed for IV sem B. E. Industrial and Production Engineering students how these concepts used in the industry I. e. Studying the gage R\&R in "Metrology and Quality Engineering" laboratory using Measurement System Analysis (MSA) tool, wherein the students need to design an experiment in order to analyze the gage $\mathrm{R} \& \mathrm{R}$ in terms of the part to be required to measure the data, instruments to be used and number of data to be collected etc. After the collection of data, gage R\&R (Repeatability and Reproducibility) has
\end{abstract}

\footnotetext{
N. Vijayakumar

Dept. Of Industrial and

Production Engineering,

B. V. B. College of Engineering and Technology, Hubballi

vijaykumar@bvb.edu
}

been analyzed using MINITAB software and the capability of gage to be inspected was assessed by the students. Through this open ended activity, the ABET $3 \mathrm{~b}$ program outcome was measured and analyzed

Key words: Blooms taxonomy, Gage R\&R, Design of experiments (DOE), Measurement system analysis (MSA).

\section{Introduction}

Bloom's taxonomy was developed to provide a common language for teachers to discuss and exchange learning and assessment methods. Specific learning objectives can be derived from the taxonomy, though it is most commonly used to assess learning on a variety of cognitive levels. [1]

The figure 1 shows the revised blooms taxonomy showing an upward arrow indicating the level of difficulty in designing an activity in order to move from a lower level to a higher level of learning.

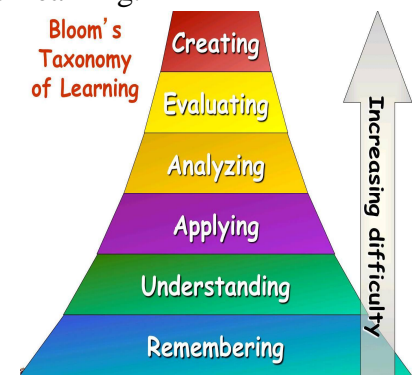

Fig. 1. Revised blooms taxonomy.

"MEASURE FOR MEASURE" is a word which tells about the need for a reliable measurement system, which is used in decision making in a manufacturing industry. Despite the quality being a major concern for manufacturing organizations, experts in manufacturing industries, express their anxiety about the measurement reliability, which is 
used in decision making [2]. The quality of the data measured is vital for appropriate understanding, monitoring or improving a process. If the data are contaminated with errors, it could lead to wrong decisions. The ability to make the right decisions depends on the availability of a measurement process, selecting the right measurement process and operating the measurement process in the correct manner. When the data quality is low, the benefits of a measurement system are also low; likewise when the data quality is high, the benefit is high too [3].

The measurement systems analysis (MSA) assesses the adequacy of a measurement system for a given application. In measuring the output from a process, there are two sources of variation, namely, part-to-part variation and measurement system variation.

Before you collect data from the process in order to analyze and control the process, use measurement system analysis (MSA) to confirm that the measurement system measures consistently and accurately, and adequately.

Minitab is a statistical package designated mainly as a teaching tool. Although, it is easy to use, it is quite powerful and flexible for moderate size data sets.

Minitab allows to store a worksheet of data and does some statistical manipulations with it.

Outcome $3 \mathrm{~b}$ of ABET (desiging and conducting experiments and analyzing and interpreting data) They developed learning objectives for the six levels of learning in Bloom's taxonomy for four different outcome elements:

- Designing experiments

- Conducting experiments

- Analyzing data

- Interpreting data

Designing Experiments: Design an experiment to (insert one or more goals or functions) and report the results (insert specifications regarding the required scope and structure of the report). Variants of this objective could be used in traditional lecture courses as well as laboratory courses.

Conducting Experiments: Conduct (or simulate) an experiment to (insert specifications about the goals of the experiment) and report the results (insert specifications regarding the scope and structure of the report).

Analyzing Data: Develop a mathematical model or computer simulation to correlate or interpret experimental results (insert specifications regarding the experiment and the data). The results may be real data from a laboratory experiment or simulated data given to students in a lecture course.

Interpreting Data: List and discuss several possible reasons for deviations between predicted and measured results from an experiment, choose the most likely reason and justify the choice, and formulate a method to validate the explanation.

\section{Measurement System Variation:-}

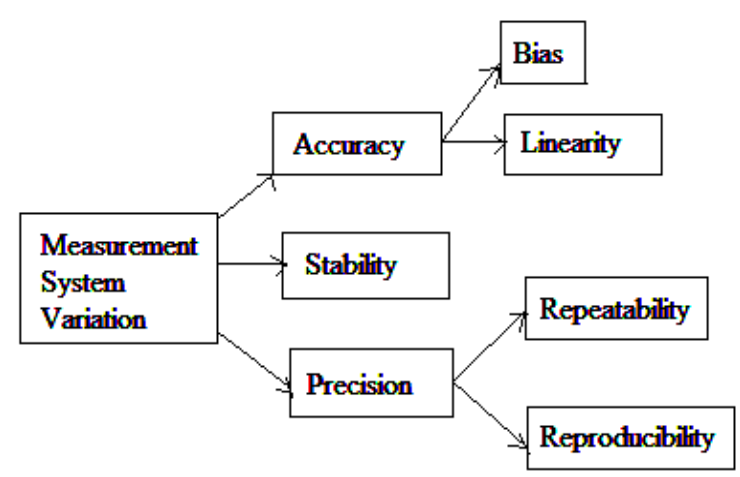

Fig. 2. Measurement system variation

The measurement system variation is shown in Fig.2 and they are classified into two categories:

Accuracy: -The difference between the part's measured and actual value

Precision: - The variation when the same part is measured and a master value repeatedly with the same device.

Errors of one or both of these categories may occur within any measurement system which is as shown in fig. 3 were the four situations are shown. For example, a device may measure parts precisely and accurately, the device may be inaccurate but measurement may be more precise. Or a device may be accurate, but not precise (the measurements have large variance). Or a device measures are inaccurate and not precise.
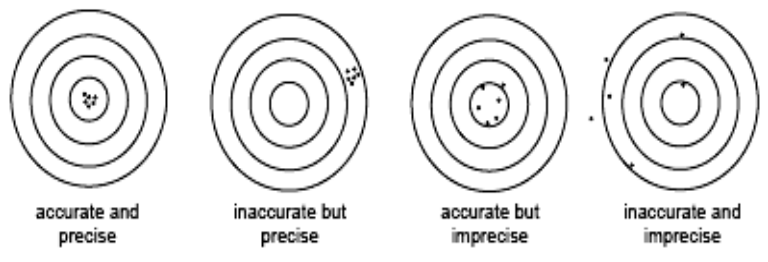

Fig 3. Accuracy Vs Precision

Accuracy can be divided into three components:

1. Bias: It is the difference between the average observed value and the reference value of the same characteristic of the same part.

2. Linearity: It is the difference in bias values over the expected operating range of the measurement gage. Stability: It is the variation (differences) in the average over extended periods of time using the same gage and an appraiser to repeatedly measure the same part.

Precision can be divided into two components:

Repeatability: - The variation due to the measuring device, or the variation observed when the same operator measures the same part repeatedly with the same device.

Reproducibility: - The variation due to the measuring system, or the variation observed when different operators measure the same part using the same device.

If the operator gets the same measurement during the repeated trials, the Gage is said to have high repeatability. Poor repeatability could be due to the device being inaccurate, the instructions being faulty, the operator not following the instructions, or a number of other factors. Fig. 4 shows the schematic of repeatability. 


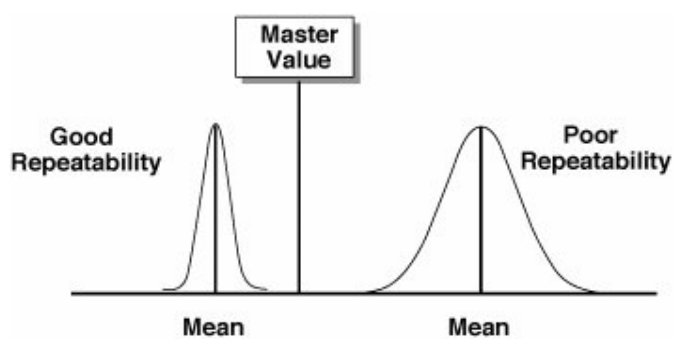

Fig. 4 Repeatablity

If several different operators get the same result when measuring the same object, the measurement device is said to have high reproducibility. This does not mean the device is accurate, but simply that the same result is produced over time. Fig. 5 shows the schematic of reproducibility

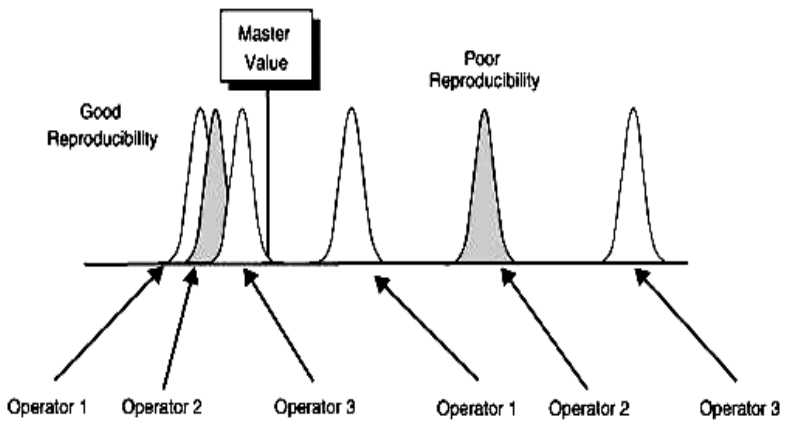

Fig. 5 Reproducablity

\section{Gage R\&R:-}

The purpose of Gage $R \& R$ study is to determine the amount of variability in the collected data that is due to the measurement system, isolate the sources of variability in the measurement system, assess whether the measurement system is suitable for broader application and quantify the variability in the measurement process attributed by the operators, parts and operators-part interaction. [3]

Analysis of Variance (ANOVA)

ANOVA is a statistical technique that estimates the amount of variability induced in measurements of the measurement system itself, and compares it to the total variability observed in order to determine the viability of the measurement system. The ANOVA technique tests the hypotheses of mean biases of the experiment and also provides the estimates of the variance components attributed to gage and operator.

\section{Objectives}

The specific objectives of the current initiative in the metrology laboratory are

- Achieve higher order of learning.

- Determine whether the measurement systems is adequate or not

- Predict how the precision of a measurement system affects the variability of a measurement using a crossed gage R\&R study.

Automotive Industry Action Group (Aiag Msa Gage R\&R \% Guidelines)
Measurement systems whose purpose is to analyze a process, a general thumb rule for acceptability of measurement system is as shown in table 1

Table 1. AIAG MSA Gage R\&R \% Guidelines [4,5]

\begin{tabular}{|c|c|c|}
\hline $\begin{array}{l}\% \quad \text { Gage } \\
\text { R\&R }\end{array}$ & Decision & Comments \\
\hline Under 10 & $\begin{array}{l}\text { Generally } \\
\text { considered to be } \\
\text { an acceptable } \\
\text { measurement } \\
\text { system. }\end{array}$ & $\begin{array}{l}\text { Recommended, especially } \\
\text { useful when trying to sort } \\
\text { or classify parts or when } \\
\text { tightened process control } \\
\text { is required. }\end{array}$ \\
\hline 10 to 30 & $\begin{array}{lr}\text { May } & \text { be } \\
\text { acceptable for } \\
\text { some } \\
\text { applications. }\end{array}$ & $\begin{array}{l}\text { A decision should be } \\
\text { based upon, for example, } \\
\text { the importance of the } \\
\text { application measurement, } \\
\text { cost of measurement } \\
\text { devices, and the cost of } \\
\text { rework or repair. Should } \\
\text { be approved the customer. }\end{array}$ \\
\hline Over 30 & $\begin{array}{l}\text { Considered to be } \\
\text { unacceptable }\end{array}$ & $\begin{array}{l}\text { Every effort should be } \\
\text { made to improve the } \\
\text { measurement system. }\end{array}$ \\
\hline
\end{tabular}

\section{METHODOLOGY:-}

There are some concepts in theory courses are being taught at the understanding level and the students could only remember these concepts. But the current initiative helped the students to gain knowledge about the concept through open ended activity for IV semester students of Industrial \& Production engineering. The activity started with the formation of batches of 4 to 5 students and then they were given a problem for studying the gage $R \& R$, where they need to check the adequacy of the measurement system by conducting gage Repeatability and Reproducibility (R\&R) study using the MINITAB software.

For the gage R\&R study, a standard order format is generated from the collection of data for the manufactured parts with specified tolerance as shown in Fig.6. Once the data are collected using gage, then it is to be analyzed. In the current activity, MINITAB software is used to analyze the data. Table 2 presents the data collection sheet.

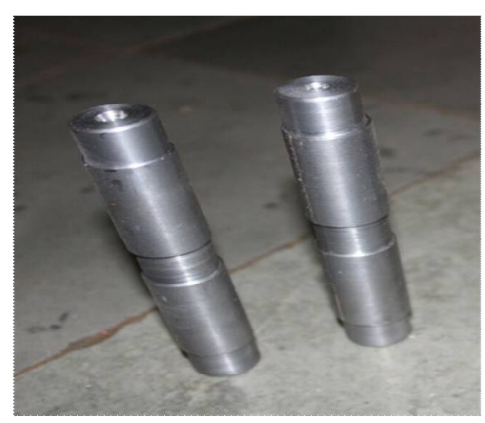

Fig. 6 Manufactured parts for Gage R\&R study

Table 2. Experimental Data collection sheet

\begin{tabular}{|l|l|l|}
\hline $\begin{array}{l}\text { Metrology and quality engineering lab (IPL213) } \\
\text { (Open ended experiment) }\end{array}$ \\
\hline Operator & Roll No. & Name of Student \\
\hline 1 & & \\
\hline 2 & & \\
\hline
\end{tabular}




\begin{tabular}{|l|l|l|l|}
\hline 3 & \multicolumn{2}{|c|}{$\begin{array}{c}\text { Date of study: } \\
\text { Reported By: }\end{array}$} \\
\hline $\begin{array}{l}\text { Gage name: G2 } \\
\text { Tolerance given: }\end{array}$ & \multicolumn{3}{|l|}{} \\
\hline Experimental plan for gage R\&R study \\
\hline $\begin{array}{l}\text { Run } \\
\text { Order }\end{array}$ & Part & Operator & $\begin{array}{l}\text { Diameter } \\
\text { measured }\end{array}$ \\
\hline & & & \\
\hline
\end{tabular}

\section{Results And Discussion:-}

Analysis carried out by B1 Team is summarized below. The students manufactured part to a tolerance of $20 \pm 0.1$ $\mathrm{mm}$ and the measured diameter with a vernier calliper. The data collected is illustrated in Table 3 .

Table 3. Data collected

\begin{tabular}{|c|c|c|c|}
\hline \multicolumn{4}{|c|}{$\begin{array}{l}\text { Metrology and quality engineering lab (IPL213) } \\
\text { (Open ended experiment) }\end{array}$} \\
\hline \multicolumn{2}{|c|}{ Operator } & Roll No. & Name of Student \\
\hline \multicolumn{2}{|c|}{1} & A & $\mathrm{X}$ \\
\hline \multicolumn{2}{|l|}{2} & $\mathrm{~B}$ & $\mathrm{Y}$ \\
\hline \multicolumn{2}{|l|}{3} & $\mathrm{C}$ & $\mathrm{Z}$ \\
\hline \multicolumn{4}{|c|}{$\begin{array}{l}\text { Gage name: G2 Date of study: 28/04/2015 } \\
\text { Tolerancegiven:20 } \pm 0.1 \mathrm{~mm} \text { Reported By: B1(Team- } \\
\text { 1) }\end{array}$} \\
\hline \multicolumn{4}{|c|}{ Experimental plan for gage R\&R study } \\
\hline $\begin{array}{l}\text { Run } \\
\text { Order }\end{array}$ & Part & Operator & $\begin{array}{l}\text { Diameter measured } \\
(\mathbf{m m})\end{array}$ \\
\hline 1 & 3 & 1 & 20.02 \\
\hline 2 & 1 & 1 & 20.02 \\
\hline 3 & 2 & 1 & 20.04 \\
\hline 4 & 2 & 2 & 20.00 \\
\hline 5 & 1 & 2 & 20.08 \\
\hline 6 & 3 & 2 & 20.02 \\
\hline 7 & 1 & 3 & 20.02 \\
\hline 8 & 2 & 3 & 20.02 \\
\hline 9 & 3 & 3 & 20.04 \\
\hline 10 & 2 & 1 & 20.04 \\
\hline 11 & 1 & 1 & 20.02 \\
\hline 12 & 3 & 1 & 20.02 \\
\hline 13 & 2 & 2 & 20.00 \\
\hline 14 & 3 & 2 & 20.10 \\
\hline 15 & 1 & 2 & 20.02 \\
\hline 16 & 2 & 3 & 20.04 \\
\hline 17 & 3 & 3 & 20.02 \\
\hline 18 & 1 & 3 & 20.04 \\
\hline 19 & 2 & 1 & 20.04 \\
\hline 20 & 3 & 1 & 20.00 \\
\hline 21 & 1 & 1 & 20.04 \\
\hline 22 & 1 & 2 & 20.02 \\
\hline 23 & 2 & 2 & 20.02 \\
\hline 24 & 3 & 2 & 20.02 \\
\hline 25 & 2 & 3 & 19.80 \\
\hline 26 & 3 & 3 & 20.08 \\
\hline 27 & 1 & 3 & 20.02 \\
\hline
\end{tabular}

Analysis

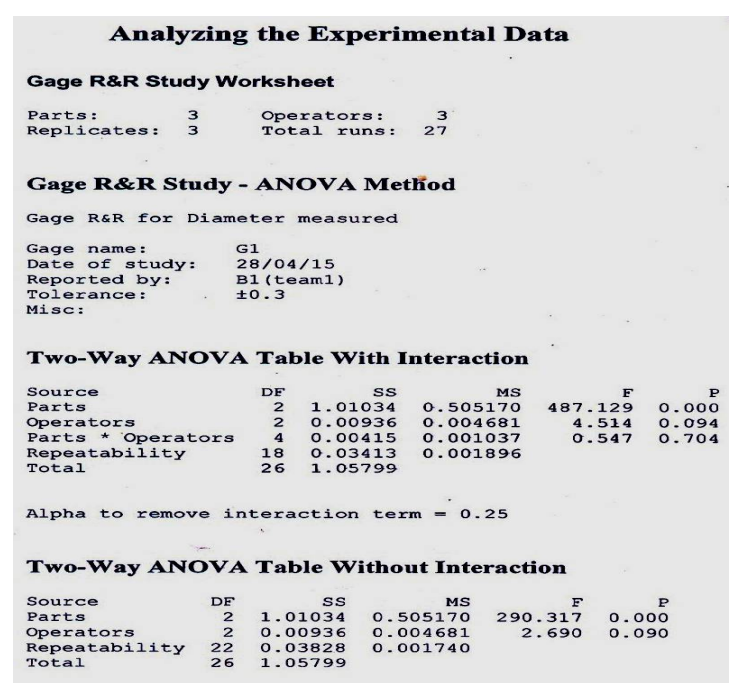

Fig. 7. Anova Results

The analysis of variance (ANOVA) has been performed using MINITAB software is shown in figure7 to know the relative importance for each of the parameters. The summary of ANOVA is presented in Table IV. It is evident from ANOVA that the $p$ value of the parts is less than 0.05 , which clearly indicates that there is a significant difference between the parts. However, $p$ value of operators and part*operator interaction is greater than the significance level and it can be concluded that there is no significant difference among the operators as well as the interaction due to part and operator .

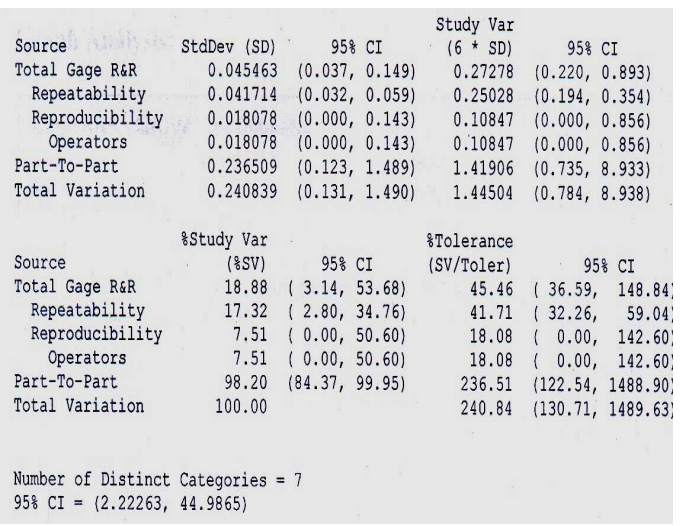

Fig 8. Gage R\&R

The Gage R \& R study has also been carried out using the MINITAB software. As shown in Fig. 8, the total gage $\mathrm{R} \& \mathrm{R}$ of \% study variation is $18.88 \%$ i.e. Less than $30 \%$ and hence the measurement system is acceptable depending upon the application. 


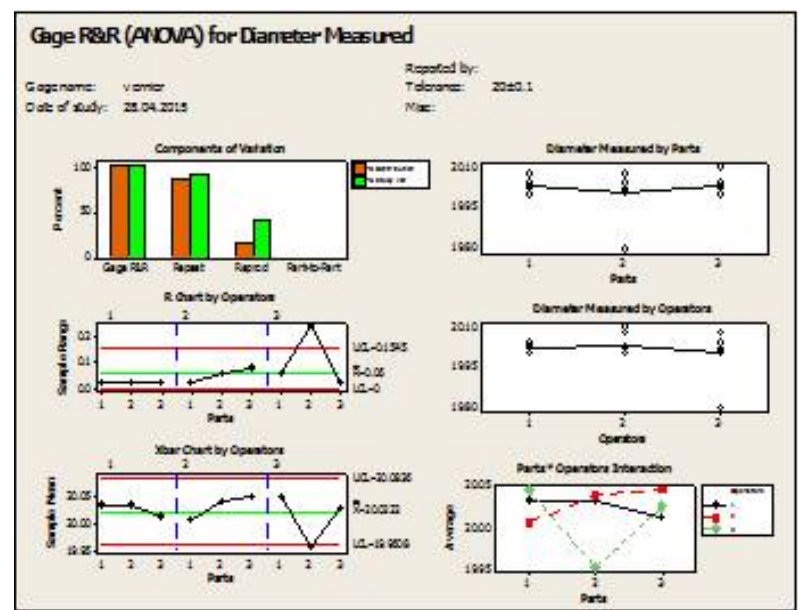

Fig 9. Graphical results

Fig 9 shows the graphical representation of diameter meter measured by different operator variation in measurement and the interaction between operator and the part.

5. ASSESSMENT

Assessment of the open ended activity was done and ABET ' $3 b$ ' outcome was measured. The attainment of each of the outcome elements is analyzed as per the rubrics which is as shown in the APENDIX. The students were evaluated for each of the outcome element through demonstration, presentation and viva-voce examination. The attainment of each of the outcome elements for $3 b$ was recorded which is as shown in Fig 10. The overall class attainment of program outcome ' $3 \mathrm{~b}$ ' was found to be $60.55 \%$.

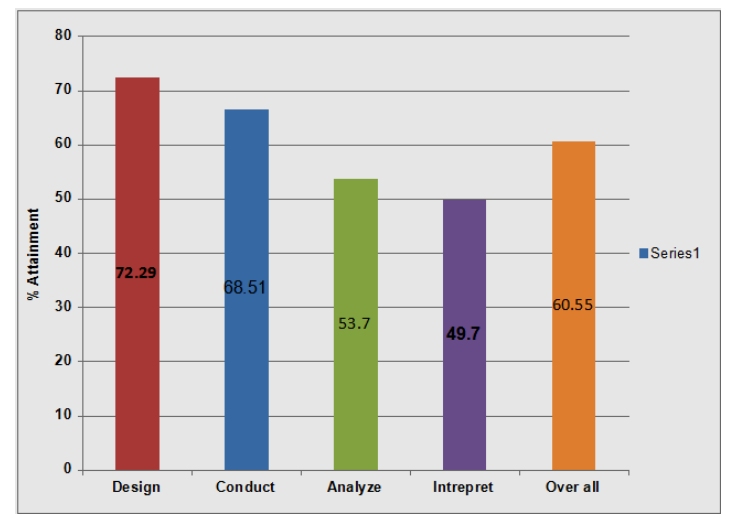

Fig 10. Attainment of Outcome elements

\section{Conclusion}

In order to address some of the industry based theoretical concepts, which are taught at Remembering levels of blooms taxonomy in the classroom, the open ended activity based learning carried out in the metrology laboratory helped the students to achieve at a higher order of learning i.e. Analyzing and also will give an exposure to check the adequacy of the measurement system before it is used for measurement of the part and to ensure the quality of the product manufactured. This initiative really helped the students to realize how the design of experiments (DOE) can be used to monitor and improve the process quality. Further, through this activity we are able to address the program outcome ABET ' $3 b$ '.

\section{Acknowledgment}

The authors would like to thank Dr. Ashok Shettar Principal. and Dr. B.B. Kotturshettar, Professor and Head, Department of Industrial \& Production Engineering, BVBCET, Hubli for their continuous guidance and motivation for this innovative practice. Authors also thank Instructors of Machine shop as well as Metrology and Quality Engineering lab for their constant support during the execution of this activity.

\section{REFERENCES}

1) Anderson, L. W., \& Krathwohl, D. R. (Eds.). (2001). A taxonomy for learning, teaching and assessing: A revision of Bloom's Taxonomy of educational objectives: Complete edition, New York : Longman.

2) Afrooz Moatari Kazerouni, "Design and Analysis of Gage R\&R Studies: Making Decisions Based on ANOVA Method", World Academy of Science, Engineering and Technology 52 (2009)

3) Burdick, R. K., Borror, C. M., and Montgomery, D. C. (2005), Design and Analysis of Gage R\&R Studies: Making Decisions with Confidence Intervals in

4) AIAG:Automotive Industry Action Group(2002), "Measurement Systems Analysis, Reference Manual"; third ed. ,Detroit,MI

5) L.A. Brown, B.R. Daugherty and V.W. Lowe, Measurement Systems Analysis, third edition, Auto Industry Action Group, 2003. 
Rubrics

\begin{tabular}{|c|c|c|c|c|c|}
\hline Outcome Element & Performance Indicators(PI) & $0-25 \%$ & $26-50 \%(2)$ & $51-75 \%$ & $76-100 \%$ \\
\hline \multirow{3}{*}{ 1.Design an experiment } & $\begin{array}{l}\text { Define goal and objectives of the } \\
\text { experiment }\end{array}$ & $\begin{array}{l}\text { Incapable of defining objective of } \\
\text { experiment. }\end{array}$ & $\begin{array}{l}\text { Some understanding of objective } \\
\text { of experiment, }\end{array}$ & $\begin{array}{l}\text { Overall sound understanding of objective } \\
\text { of experiment, , sample size, method of } \\
\text { collection of data. Does not significantly } \\
\text { impair solution. }\end{array}$ & $\begin{array}{l}\text { Clear and complete understanding objective } \\
\text { of experiment, sample size, method of } \\
\text { collection of data. }\end{array}$ \\
\hline & $\begin{array}{l}\text { Identify the dependent and independent } \\
\text { variables of a problem }\end{array}$ & $\begin{array}{l}\text { Incapable of selecting, sample size } \\
\text {,causes of variation in measurement } \\
\text { process }\end{array}$ & $\begin{array}{l}\text { Some understanding of selecting, } \\
\text { sample size, and reasons for } \\
\text { variation in measurement }\end{array}$ & $\begin{array}{l}\text { Overall sound understanding in sample } \\
\text { size, and reasons for variation in } \\
\text { measurement }\end{array}$ & $\begin{array}{l}\text { Clear in selecting sample size. and un } \\
\text { understanding reasons for variations in } \\
\text { measurement process }\end{array}$ \\
\hline & $\begin{array}{l}\text { Determine the appropriate number of } \\
\text { data points }\end{array}$ & $\begin{array}{l}\text { Incapable of determining number of } \\
\text { data points }\end{array}$ & $\begin{array}{l}\text { Able to determining number of } \\
\text { data points }\end{array}$ & $\begin{array}{l}\text { Collecting acceptable number of data } \\
\text { points. }\end{array}$ & Collected exact number of data points. \\
\hline \multirow{4}{*}{ 2. Conduct } & Familiarize with the equipment & $\begin{array}{l}\text { In capable of familiarizing with } \\
\text { machine, Inspection (calibration), } \\
\text { collection of data, and measure of } \\
\text { the process performance }\end{array}$ & $\begin{array}{l}\text { Some deficiencies in exploring. } \\
\text { of familiarizing with machine, }\end{array}$ & $\begin{array}{l}\text { Some understanding of machine, } \\
\text { inspection (calibration). }\end{array}$ & $\begin{array}{l}\text { Clear and complete understanding, machine } \\
\text { Inspection (calibration). }\end{array}$ \\
\hline & Calibrate the instruments to be used & $\begin{array}{l}\text { In capable of Inspecting the } \\
\text { calibrated instruments. }\end{array}$ & $\begin{array}{l}\text { Some deficiencies in inspection } \\
\text { (calibration). }\end{array}$ & $\begin{array}{l}\text { Overall sound understanding in using } \\
\text { calibrated instrument. }\end{array}$ & $\begin{array}{l}\text { Clear and complete understanding in using } \\
\text { calibrated instrument. }\end{array}$ \\
\hline & $\begin{array}{l}\text { Follow the proper procedure to collect } \\
\text { the data }\end{array}$ & $\begin{array}{l}\text { Improper procedure adopted for data } \\
\text { collection. }\end{array}$ & $\begin{array}{l}\text { Marginally acceptable procedure } \\
\text { adopted for collection of data. }\end{array}$ & $\begin{array}{l}\text { Overall sound understanding the } \\
\text { procedure of data collection }\end{array}$ & $\begin{array}{l}\text { Clear and complete understood the proper } \\
\text { procedure for data collection. }\end{array}$ \\
\hline & $\begin{array}{l}\text { Measure the performance of the } \\
\text { product/process }\end{array}$ & $\begin{array}{l}\text { Inadequate measurement of the } \\
\text { performance of product/process. }\end{array}$ & $\begin{array}{l}\text { Marginally } \\
\text { measurement of adequate } \\
\text { product/process performance. }\end{array}$ & $\begin{array}{l}\text { Overall sound understanding measure of } \\
\text { the process performance. }\end{array}$ & $\begin{array}{l}\text { Satisfactorily measured of the process } \\
\text { performance }\end{array}$ \\
\hline \multirow{3}{*}{ 3. Analyze data } & Carry out the necessary calculations. & $\begin{array}{l}\text { Serious deficiencies in understanding } \\
\text { the correct selection and/or use of } \\
\text { tools for analyzing data. }\end{array}$ & $\begin{array}{l}\text { Minimal ability to conduct } \\
\text { calculations. }\end{array}$ & $\begin{array}{l}\text { Overall acceptable in carrying out the } \\
\text { necessary calculations. }\end{array}$ & $\begin{array}{l}\text { Clear understanding in carrying out the } \\
\text { necessary calculations. }\end{array}$ \\
\hline & Perform an error analysis & $\begin{array}{l}\text { Serious deficiencies in understanding } \\
\text { and using correct tools for analyzing } \\
\text { data. }\end{array}$ & $\begin{array}{l}\text { Minimal application and use of } \\
\text { appropriate tools for analyzing } \\
\text { the collected data. }\end{array}$ & $\begin{array}{l}\text { Moderately acceptable in performing an } \\
\text { error analysis. }\end{array}$ & Satisfactorily performed error analysis. \\
\hline & $\begin{array}{l}\text { Tabulate and plot the results using } \\
\text { appropriate choice of variables and } \\
\text { software }\end{array}$ & $\begin{array}{l}\text { Serious deficiencies in understanding } \\
\text { of tabulation and plots of results. }\end{array}$ & $\begin{array}{l}\text { Minimal ability of } \\
\text { tabulation/plotting results using } \\
\text { appropriate choice of software }\end{array}$ & $\begin{array}{l}\text { Computer-aided tools used with moderate } \\
\text { effectiveness to analyze the collected data }\end{array}$ & $\begin{array}{l}\text { Computer-aided tools are used effectively } \\
\text { to develop and analyze collected data. }\end{array}$ \\
\hline 4. Interpret data & $\begin{array}{l}\text { Make observations and draw } \\
\text { conclusions regarding the variation of } \\
\text { the parameters involved }\end{array}$ & $\begin{array}{l}\text { Incapable of interpret the analyzed } \\
\text { data }\end{array}$ & $\begin{array}{l}\text { Serious deficiencies in interpret } \\
\text { the analyzed data }\end{array}$ & $\begin{array}{l}\text { Some understanding of interpret the } \\
\text { analyzed data. }\end{array}$ & $\begin{array}{l}\text { Clear and complete understanding of the } \\
\text { interpretation of analyzed data }\end{array}$ \\
\hline
\end{tabular}


Compare with predictions from theory Incapable making predictions for or design calculations and explain any future course of action to control the discrepancies.
Serious deficiencies observed in Some understanding interpreting th predicting future course of action to control the process
Satisfactorily analyzed the data and has made predictions for future course of action to control the process 